\title{
High-Resolution Dynamical Downscaling of ERA-Interim Using the WRF Regional Climate Model for the Area of Poland. Part 1: Model Configuration and Statistical Evaluation for the 1981-2010 Period
}

\author{
Maciej Kryza, ${ }^{1}$ Kinga Wałaszek, ${ }^{1}$ Hanna Ojrzyńska, ${ }^{1}$ Mariusz Szymanowski, ${ }^{2}$ Małgorzata Werner,,${ }^{1,3}$ and \\ ANTHONY J. DORE ${ }^{4}$
}

\begin{abstract}
In this work, we present the results of high-resolution dynamical downscaling of air temperature, relative humidity, wind speed and direction, for the area of Poland, with the Weather Research and Forecasting (WRF) model. The model is configured using three nested domains, with spatial resolution of $45 \mathrm{~km} \times$ $45 \mathrm{~km}, 15 \mathrm{~km} \times 15 \mathrm{~km}$ and $5 \mathrm{~km} \times 5 \mathrm{~km}$. The ERA-Interim database is used for boundary conditions. The results are evaluated by comparison with station measurements for the period 1981-2010. The model is capable of reproducing the main climatological features of the study area. The results are in very close agreement with the measurements, especially for the air temperature. For all four meteorological variables, the model performance captures seasonal and daily cycles. For the air temperature and winter season, the model underestimates the measurements. For summer, the model shows higher values, compared with the measurements. The opposite is the case for relative humidity. There is a strong diurnal pattern in mean error, which changes seasonally. The agreement with the measurements is worse for the seashore and mountain areas, which suggests that the $5 \mathrm{~km} \times 5 \mathrm{~km}$ grid might still have an insufficient spatial resolution. There is no statistically significant temporal trend in the model performance. The larger year-to-year changes in the model performance, e.g. for the years 1982 and 2010 for the air temperature should therefore be linked with the natural variability of meteorological conditions.
\end{abstract}

Key words: Dynamical downscaling, high resolution, WRF model, Poland.

1 Department of Climatology and Atmosphere Protection, Institute of Geography and Regional Development, Wrocław University, ul. Kosiby 8, 51-621 Wrocław, Poland. E-mail: maciej.kryza@uwr.edu.pl

2 Department of Geoinformatics and Cartography, Institute of Geography and Regional Development, Wrocław University, pl. Uniwersytecki 1, 50-137 Wrocław, Poland.

3 National Pollen and Aerobiology Research Unit, University of Worcester, Henwick Grove, Worcester WR2 6AJ, UK.

4 Centre for Ecology and Hydrology, Bush Estate, Penicuik, Midlothian EH26 0QB, UK.

\section{Introduction}

Downscaling is a method used to obtain geographical distribution and time evolution of smallscale features given large-scale coarse-resolution analyses, forecasts or simulations (HoNG and KANAMITSU 2014). There are two main downscaling methods: statistical and dynamical (BENESTAD 2008). Dynamical downscaling utilizes a dynamical regional model, forced by coarse-resolution data (GIORGI and BAtEs 1989). Statistical downscaling is based on the relations between the large-scale parameters and regional-scale observations (KIM et al. 1984). Both approaches were compared, e.g. by Нuth et al. (2015). There is also a combined approach, named statistical-dynamical downscaling, which has also gained importance in climate research in recent years. Statistical-dynamical downscaling combines the benefit of both the statistical and dynamical approaches, and was presented, e.g. by FuENTES and Heimann (2000) and Reyers et al. (2015). Here, the work is focused on dynamical downscaling at high spatial resolution. High-resolution models benefit, e.g. from detailed surface forcing information, including topography and land use, and local features, like sea breeze, can be explicitly resolved (HeIKKILA et al. 2011; SoAres et al. 2012; CZernecki 2013). With the grid scale smaller than several kilometres, the explicit treatment of the entrainment process at the top of the planetary boundary layer may be applied and the advantages of this were shown, e.g. by Hong and Dudhia (2012). There is also certain criticism related with dynamical downscaling and high resolution. This has been addressed, e.g. by 
Pielke (2013) and Murphy (1999), and is mainly related to the regional model and its settings. Many parameterization schemes, utilized in regional studies, were developed for coarse resolutions. This may lead to high positive bias in precipitation, which was reported, e.g. by Shrestha et al. (2013). The development of the precipitation physics parameterization scheme for a smooth transition to cloud resolving scales is now in progress (Hong and Kanamitsu 2014; Grell and Freitas 2013). Other sources of uncertainty are related with large-scale fields provided by the global climate models, the unphysical treatment of the lateral boundary conditions and inconsistencies in the dynamics and physics between the global and regional climate models.

Central Europe and Poland comprise a geographical region of transitional climate, with large seasonal and year-to-year variability. There are some examples of statistical downscaling applied for this area, presented, e.g. by Marosz et al. (2013) and Marosz and JAKUSIK (2014). Examples of dynamical downscaling at high spatial resolution include simulations for short periods or limited to small areas of selected catchments (PAvlik et al. 2011; CZERnecki 2013). The results of the European Coordinated Regional Climate Downscaling Experiment (EURO-CORDEX) project show the importance of dynamical downscaling for this area and also address the uncertainties related with this approach (Giorgi and Gutowski 2015). KatraGKOU et al. (2015) show the influence of the various physics scheme on the WRF model performance for Europe. Kotlarski et al. (2014) show the role of model grid resolution on the results of dynamical downscaling for the EURO-CORDEX domain. The demand for meteorological information, available for a long-term period, at high spatial and temporal resolution, and developed homogenously for a large area is increasing. This information is a must for other studies, such as ecology and tick diseases (KIEWRA et al. 2014), air quality (WAłASZEK et al. 2015; WERNER et al. 2011; Hernandez-Ceballos et al. 2014) or hydrological forecasting (Jeziorska and Niedzielski, this issue).

In this work, we present the application of the WRF model for dynamical downscaling of the ERAInterim data for the area of Poland, with high spatial resolution of $5 \mathrm{~km} \times 5 \mathrm{~km}$. The model configuration is described and the results are compared with instantaneous surface meteorological measurements of air temperature, relative humidity and wind speed and direction. The model performance is summarized using both the domain-wide statistics and the spatial approach, where individual stations are assessed. In the second part of this work (OJRZYŃSKA et al. 2015, this issue), we address the model performance for daily rainfall and air temperature, and analyse the results in terms of circulation type.

\section{Data and Methods}

\subsection{Study Area}

The study is focused on the territory of Poland in Central Europe, located between $49^{\circ} 00^{\prime} \mathrm{N}$ and $54^{\circ} 50^{\prime} \mathrm{N}$, and $14^{\circ} 07^{\prime} \mathrm{E}$ and $24^{\circ} 09^{\prime} \mathrm{E}$ (Fig. 1). The area of Poland is $312679 \mathrm{~km}^{2}$, with the altitude varying between $1.8 \mathrm{~m}$ below (Northern Poland) and $2499 \mathrm{~m}$ above sea level (Southern Poland). The average height of Poland is $173 \mathrm{~m}$ a.s.l., and the areas located in zones $100-200 \mathrm{~m}$ a.s.l. (49.7\%) and $0-100 \mathrm{~m}$ a.s.1. $(25.2 \%)$ cover the majority of the country area. The regions with elevation above $1000 \mathrm{~m}$ a.s.l. cover about $0.2 \%$. Poland is characterized by transitional characteristics of climate with strong, varying maritime and continental influences and prevailing western flow. The long-term annual mean air temperature varies from ca. $9{ }^{\circ} \mathrm{C}$ in the west, to below $5{ }^{\circ} \mathrm{C}$ in the mountains and SE part of Poland. In winter and fall, the west-east gradient in air temperature is pronounced, with a warm belt along the Baltic Sea shore. In summer, the mean air temperature decreases from the south (excluding mountains) to the north. West and south-west wind directions are the most frequent, with the frequency exceeding $20 \%$. The annual mean wind speed is in the range from 3 to $4 \mathrm{~m} \mathrm{~s}^{-1}$ for the majority of the study area, with the highest values observed close to the Baltic Sea shore and in the mountains (LoRENC 2005). The annual mean relative humidity is the highest in the north of the country (>84\%; LORENC 2005) and decreases towards the south (except for the mountains). 


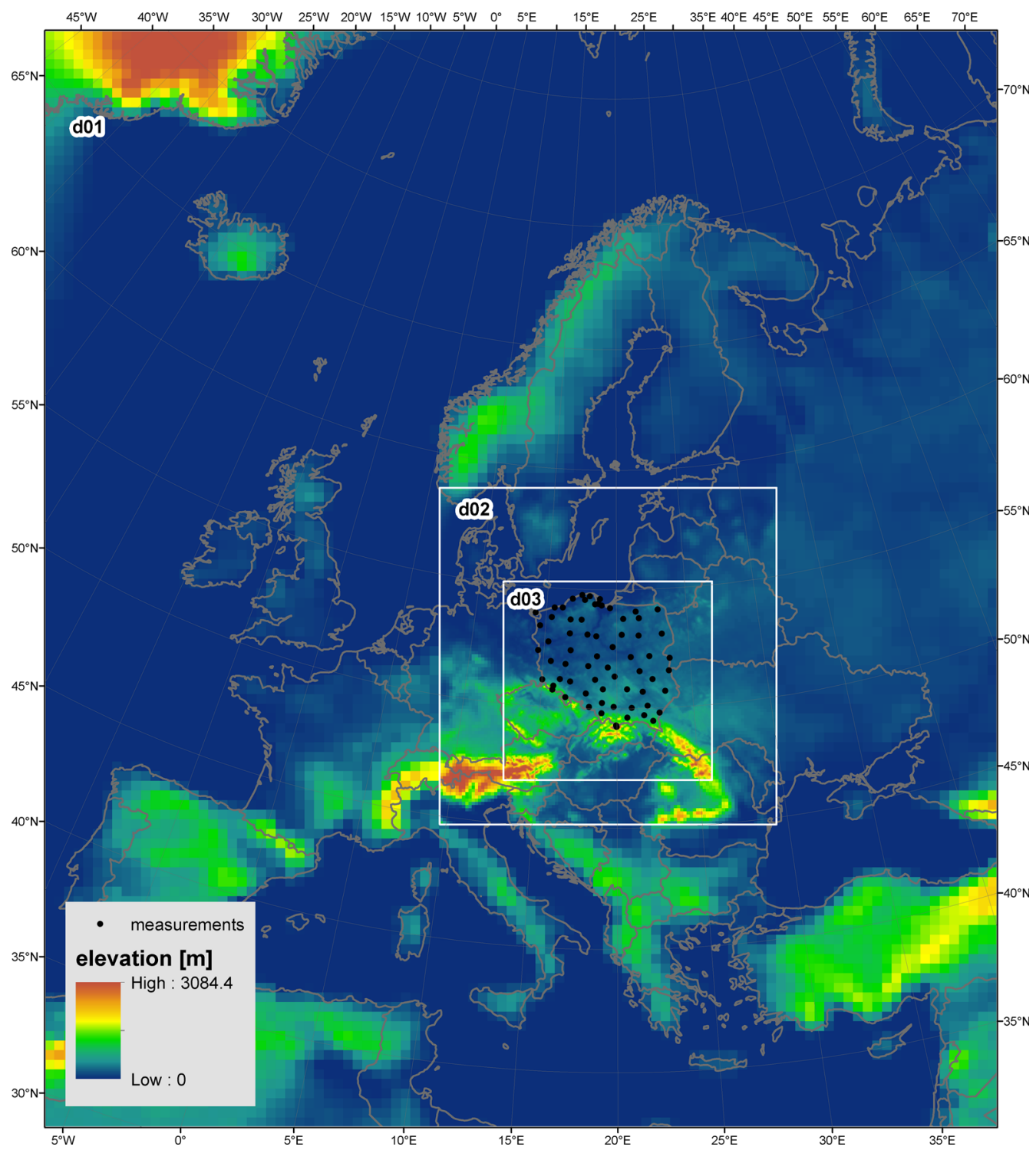

Figure 1

The WRF model domains and meteorological sites used for model evaluation

\subsection{The WRF Model Configuration}

The Advanced Research Weather Research and Forecasting Model (WRF) version 3.4.1 was used in this study (SKAMAROCK et al. 2008). The model was run, for each year separately, for the 1981-2010 period. For each year, the simulation was started 14 days in advance, and these 14 days were treated as a spin-up time and removed from the analysis. The large-scale meteorological boundary conditions were taken from the ERA-Interim reanalysis of the European Centre for Medium Range Forecasting (DEE et al. 2011). The model configuration was selected after running and evaluation of the model for the chosen test periods (KRYZA et al. 2013, 2015; WAłASZEK et al. 2014a). The WRF model configuration applied in this study includes three one-way nested domains, with spatial resolution changing from $45 \mathrm{~km} \times 45 \mathrm{~km}$ for the outermost domain (d01, 
$100 \times 115 \quad$ grid $\quad$ cells; $\quad$ Fig. 1) through $15 \mathrm{~km} \times 15 \mathrm{~km} \quad(\mathrm{~d} 02,106 \times 106$ grid cells $)$, to $5 \mathrm{~km} \times 5 \mathrm{~km}$ for the innermost domain (d03, $187 \times 195$ grid cells). All the domains have 51 vertical layers. The model configuration in terms of physics is summarized in Table 1. All the domains share the same options of physics for radiation, microphysics and boundary layer scheme. For convection, coarse-resolution domains $\mathrm{d} 01$ and $\mathrm{d} 02$ use the Kain-Fritsch scheme (KAIN 2004). For the fine resolution d03, convection is explicitly resolved.

\subsection{Meteorological Measurements}

In this study, we use meteorological measurements provided by the Polish Institute of Meteorology and Hydrology-National Research Institute (IMGW-PIB), available for 66 stations located in Poland (Fig. 1). The focus of this study is on the meteorological variables which are of wide interest for other applications, including ecology and hydrology. The model evaluation is, therefore, presented for air temperature at $2 \mathrm{~m}$ (T2), relative humidity at $2 \mathrm{~m}$ $(\mathrm{RH})$, wind speed (WSPD) and direction (WDIR) at $10 \mathrm{~m}$. The measurements were available every $3 \mathrm{~h}$. Only the data that passed the quality control at the IMGW-PIB are used for the model evaluation.

\subsection{Evaluation of the Model Results}

The WRF model results are compared with the measurements described above. For this comparison, we used the WRF model domain d03 data from a grid cell, in which the measuring site is located. It should be noticed here that we used the area averages (WRF model grid cell) and point values (measuring sites) in this work. The model error is calculated as the difference between the modelled and observed value, and the model performance was summarized using the following domain-wide error statistics:

- Mean error (ME) — calculated as the arithmetic mean from the model minus observation. This statistic indicates the general tendency for over$(\mathrm{ME}>0)$ or underestimation $(\mathrm{ME}<0)$ of the given meteorological value by the model. The expected value is zero. The units are the same as for the analysed meteorological variable. For wind direction, the ME statistic is calculated as the shortest angular distance between the mean modelled and measured wind directions. The mean wind direction was calculated using the $\mathrm{R}$ software circular package. The positive/negative values of ME for wind direction mean that the modelled wind direction is shifted clockwise/counterclockwise if compared to the measurements.

- Mean absolute error (MAE)—calculated as an arithmetic mean of the absolute values of the model errors. The expected value is zero, and the units are the same as for the analysed meteorological variable. MAE was calculated for T2, RH and WSPD.

- Index of agreement (IOA)—calculated after EMERY et al. (2001) as a standardized measure of the degree of model prediction error:

$$
\mathrm{IOA}=1-\left[\frac{I \mathrm{~J} \times \mathrm{RMSE}^{2}}{\sum_{j=1}^{J} \sum_{i=1}^{I}\left|P_{j}^{i}-M_{\mathrm{o}}\right|+\left|O_{j}^{i}-M_{\mathrm{o}}\right|}\right],
$$

- where RMSE is the square root of the meansquared difference in prediction-observation pairings with valid data within a given analysis region

Table 1

The WRF model physics options used in this study

\begin{tabular}{llll}
\hline & $\mathrm{d} 01$ & $\mathrm{~d} 02$ & $\mathrm{~d} 03$ \\
\hline Short-wave radiation & RRTMG (IACONO et al. 2008) & \\
Long-wave radiation & RRTM (MLAWER et al. 1997) & Explicitly resolved \\
Planetary boundary layer & Yonsei University scheme (HoNG et al. 2006) & \\
Cumulus convection & Kain-Fritsch (KAIN 2004) & \\
Microphysics & Goddard (TAO et al. 1989) & \\
Land surface model & Noah land surface model & \\
\hline
\end{tabular}


and for a given time, $P_{j}^{i}$ is the individual predicted quantity at site $\mathrm{i}$ and time $\mathrm{j}, O_{j}^{i}$ is the individual observed quantity at site $\mathrm{i}$ and time $\mathrm{j}$ and $M_{\mathrm{O}}$ is the observed mean. IOA varies between 0 and 1 , and the expected value is 1 (perfect model performance). IOA is unitless and was calculated for T2, RH2 and WSPD. The IOA is calculated for a given month using the 3-hourly values from all the stations and all the years considered.

- Pearson's correlation coefficient $(R)$-calculated using the $\mathrm{R}$ circular package suitable for handling circular data. This statistic was calculated for wind direction only. $\mathrm{R}$ varies between -1 and +1 and the expected value is +1 . $\mathrm{R}$ is unitless.

All the above-mentioned statistics were calculated domain-wide for the entire study period of 1981-2010 and separately for each season: winter (December, January and February, DJF), spring (March, April and May, MAM), summer (June, July and August, JJA) and fall (September, October and November, SON). ME and IOA ( $\mathrm{R}$ in the case of wind direction) were calculated also separately for each station and the season, to spatially assess the model performance. All the statistics were calculated using the model and measurements available every $3 \mathrm{~h}$.

In our study, we evaluate the model performance for the long period of 1981-2010. It is, therefore, of interest to check if the model performance shows some temporal characteristics, e.g. if the model performs better for the more recent years. We analyse this issue using the Taylor diagrams (TAYLOR 2001). In each plot, prepared separately for each season, we summarize the model performance for each year of the study period. The details on the Taylor diagrams are provided by TAYLOR (2001). Also, we apply tests for statistical significance of the ME, MAE and IOA trends in the 1981-2010 period, using Mann-Kendall tests (Mann 1945; Kendall 1970).

\section{Results}

The results are organized as follows. First, the domain-wide error statistics are presented. Second, seasonal and diurnal variability in model performance is addressed and the spatial distribution of the model errors is presented. Finally, the model performance is summarized for each year separately, using the Taylor diagrams.

The model performance is summarized for the entire domain and the period of 1981-2010 in Table 2. The model has a general tendency for overestimation of the observed air temperature. The wind speed is also slightly overestimated. The relative humidity and wind direction have negative ME. For the WDIR, this means that the wind direction is shifted counterclockwise compared with the measurements. MAE is higher compared to ME and reaches $1.7 \mathrm{~K}$ for $\mathrm{T} 2,9 \%$ for $\mathrm{RH} 2$ and $1.5 \mathrm{~m} \mathrm{~s}^{-1}$ for WSPD. In terms of Index of Agreement, the model is in very close agreement with the measurements for T2, with IOA above 0.99 (1.0 means a "perfect model performance"). For RH2 and WSPD, the Index of Agreement is lower, but still above 0.8. For WDIR, the Pearson correlation coefficient is close to 0.8 for the entire study period.

The general model performance, summarized with domain-wide statistics for the entire period 1981-2010, changes significantly if the statistics are calculated for months and seasons (Figs. 2 and 3). This is especially noticeable when ME is considered. The air temperature is underestimated for the winter months of January, February and December (Fig. 2). March and November have a mean error close to zero, and for the warm season the model overestimates the observed values of air temperature. For the relative humidity, the annual cycle in model performance is opposite, with an overestimation for cold months and underestimation for spring, summer and fall. For the wind speed, ME is above zero for all the months, except spring. The largest errors, in terms of absolute value of ME, are for late summer and fall. For the wind direction, the ME values are always below zero, and the largest errors, in terms of the absolute value of ME, are for spring and summer. IOA for T2 is very high for all the months, with slightly lower values for summer and fall. There is a strong annual cycle in IOA for relative humidity. The highest values of IOA are for the warm season months, with a drop in IOA for winter. Both the wind speed and direction show a similar annual cycle for the IOA and correlation coefficient, respectively. Cold season months have the highest values of IOA 
Table 2

Domain-wide statistics for the entire 1981-2010 period

\begin{tabular}{lllll}
\hline & T2 & RH2 & WSPD & WDIR \\
\hline ME & 0.23 & -1.45 & 0.13 & -7.60 \\
MAE & 1.66 & 8.93 & 1.45 & - \\
IOA & 0.99 & 0.86 & 0.82 & - \\
R & - & - & - & 0.78 \\
\hline
\end{tabular}

For ME and MAE, the units are $\mathrm{K}$ for $\mathrm{T} 2, \%$ for $\mathrm{RH} 2, \mathrm{~m} \mathrm{~s}^{-1}$ for WSPD and degrees for WDIR. IOA and $\mathrm{R}$ are unitless

T2

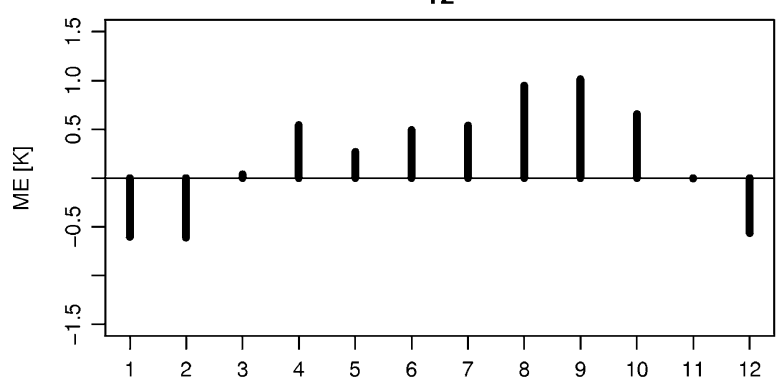

RH2

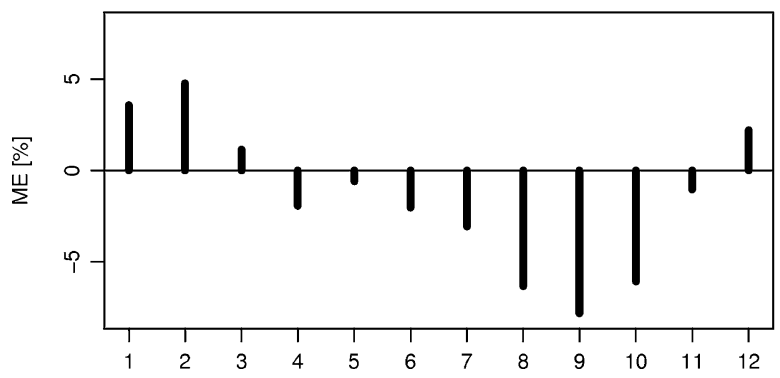

WSPD
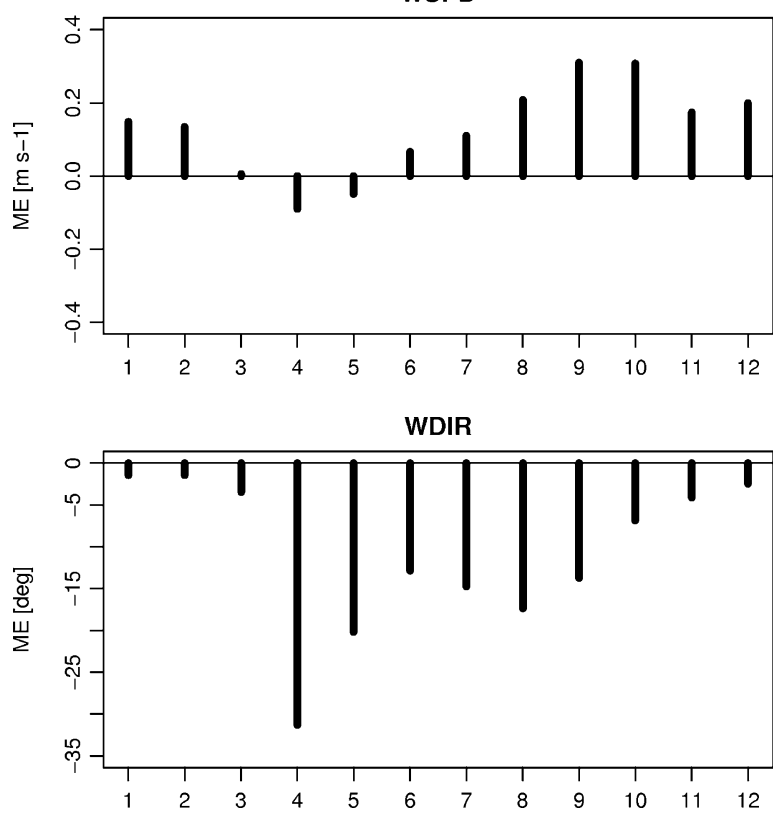

Figure 2

Domain-wide mean error for T2, WSPD, RH2 and WDIR for each month ( $x$ axis) in the 1981-2010 period

and $\mathrm{R}$. The warm season is characterized by smaller values of these statistics.

For certain months, the model errors are significantly higher compared to the general summary presented in Table 2 and, for some months, the acceptance criteria, defined by EMERY et al. (2001) for air temperature $\mathrm{ME}(-0.5 \mathrm{~K}<\mathrm{ME}<0.5 \mathrm{~K})$, are not met. Noticeably, the annual variability in IOA statistic is very small, especially for T2. Here, the acceptance criteria defined by EMERY et al. (2001) are met for T2 and WSPD (not defined for RH2 and WDIR).
Apart from the annual cycle in the model performance, the ME, MAE and IOA/R also show a daily pattern, which changes between the seasons (Figs. 4, 5). For the air temperature, ME is negative for all hours in winter and positive for summer and autumn. For winter, the largest ME, in terms of the absolute values, are calculated for night hours. For spring, summer and autumn months, the largest errors are observed for morning hours and, especially for summer and spring, are small in early afternoon. For spring, the air temperature is underestimated for 18 UTC. The relative humidity shows a reversed daily 
T2

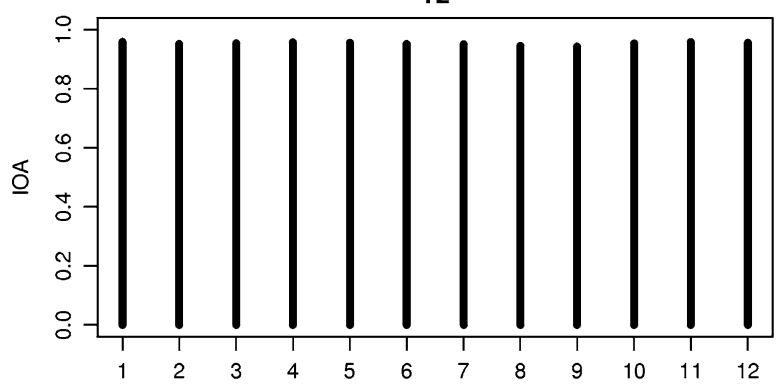

$\mathrm{RH} 2$

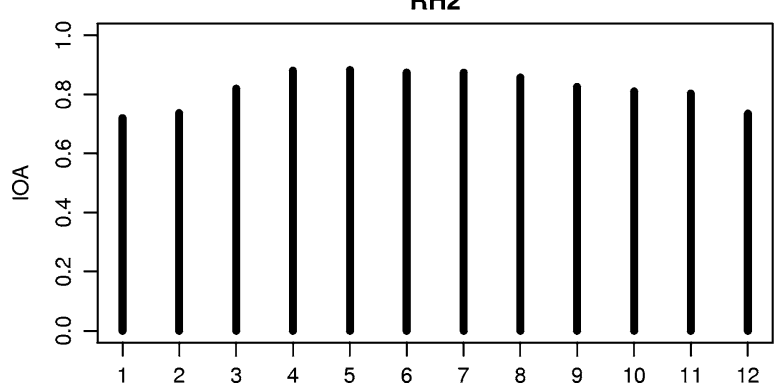

WSPD

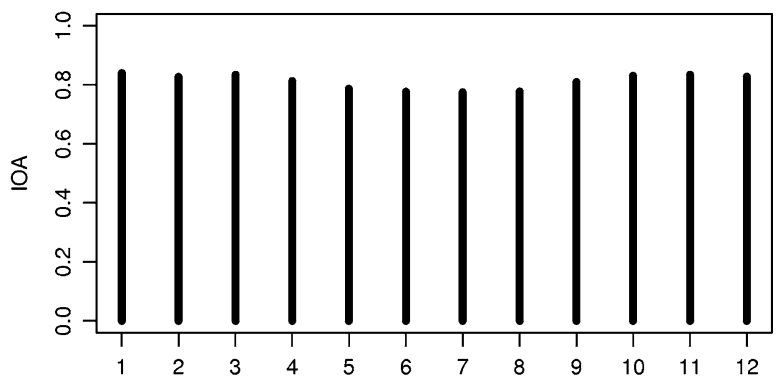

WDIR

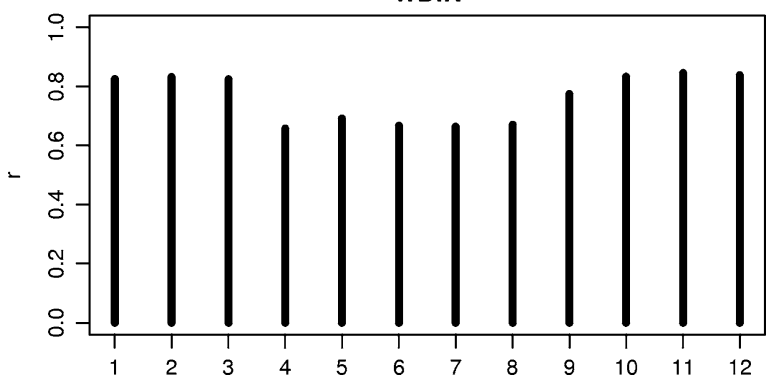

Figure 3

Domain-wide IOA for T2, WSPD, RH2 and R for WDIR for each month ( $x$ axis) in the 1981-2010 period
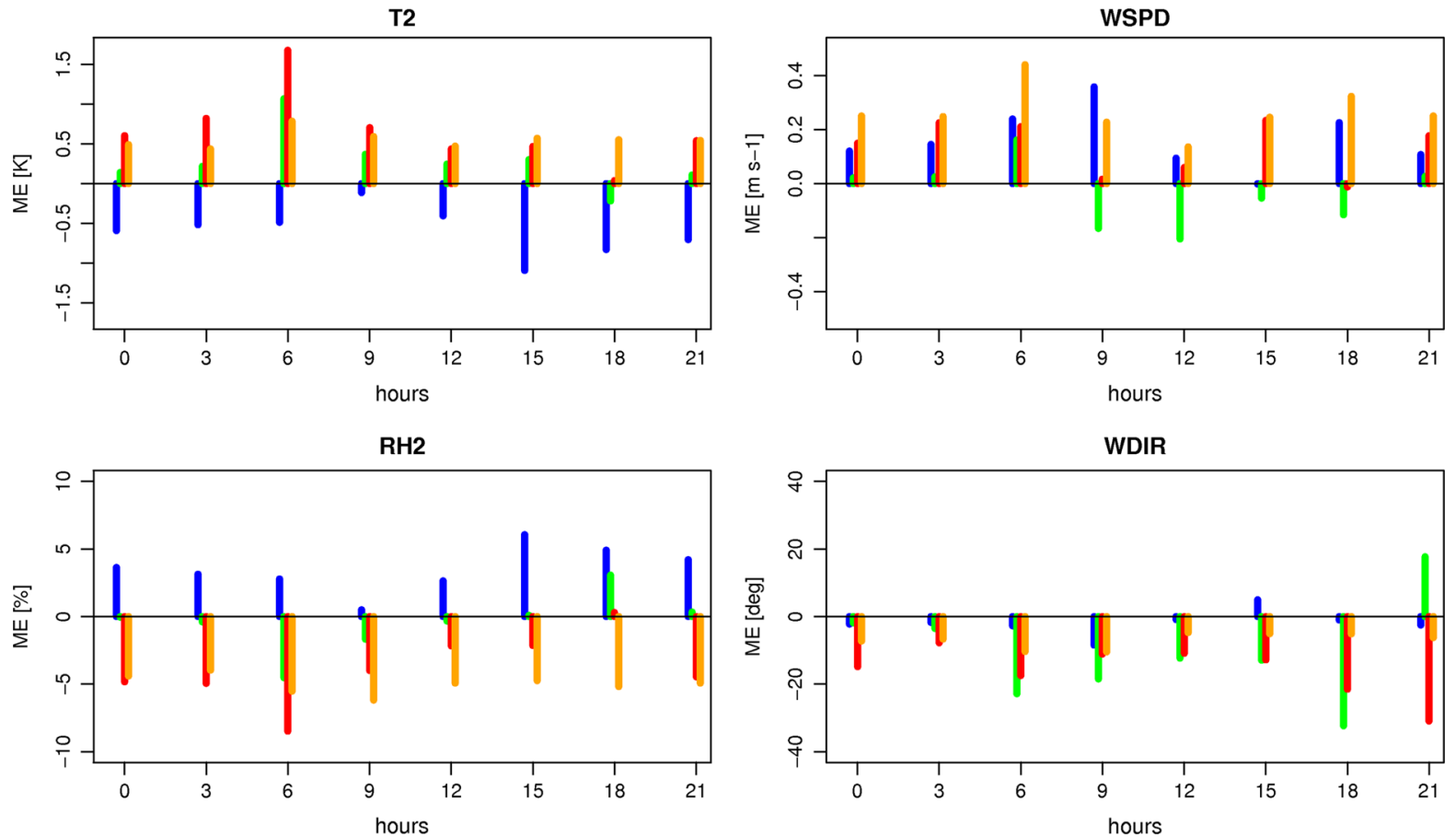

Figure 4

Daily cycle (hours- $x$ axis) in ME for T2, WSPD, RH2 and WDIR for DJF (blue), MAM (green), JJA (red) and SON (orange) 
T2

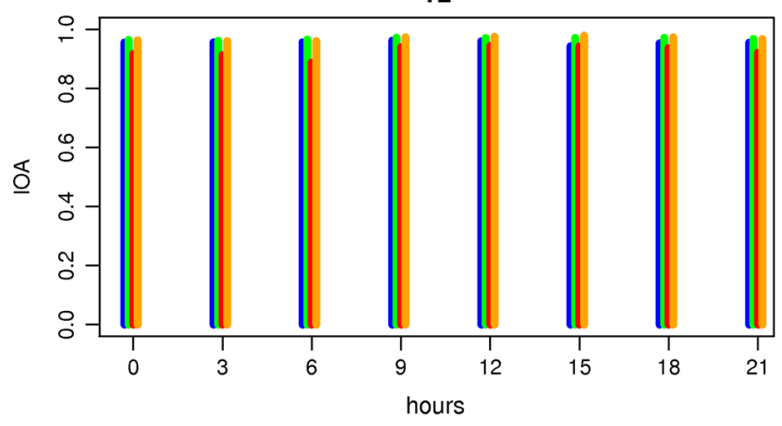

RH2

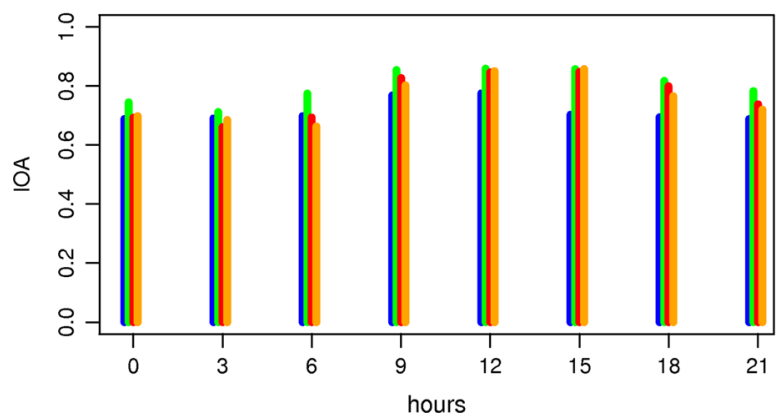

WSPD

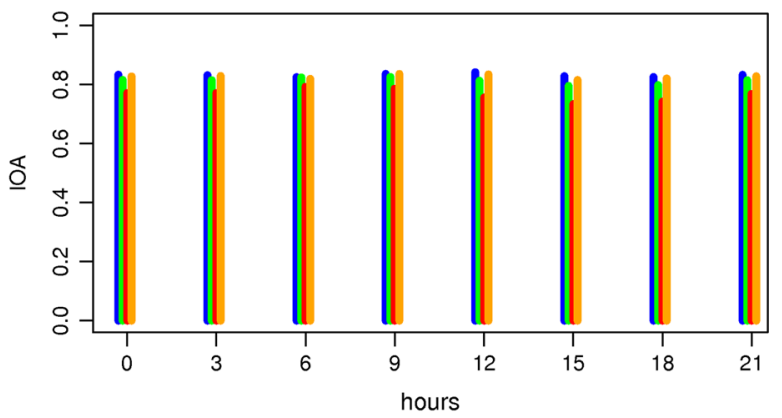

WDIR

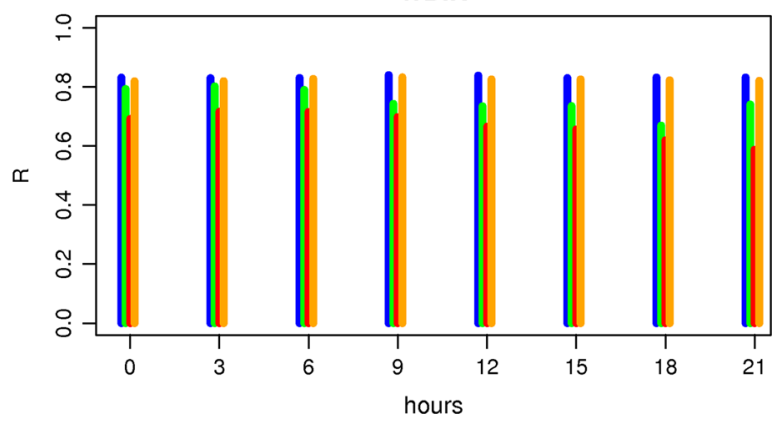

Figure 5

Daily cycle (hours- $x$ axis) in IOA for T2, WSPD, RH2 and R for WDIR for DJF (blue), MAM (green), JJA (red) and SON (orange)

cycle. It is overestimated for winter for all hours and underestimated for the remaining seasons. This underestimation shows a pronounced daily pattern for summer, but not for autumn. For autumn, RH2 ME is ca. $5 \%$ for the entire day, with slightly higher ME in terms of the absolute values for morning hours. For spring, ME is underestimated for 6 and 9 UTC and overestimated for 18 UTC. For the remaining hours, ME is close to zero.

The wind speed is overestimated for the entire day during winter, summer and autumn. For winter, ME is the highest for the night and morning hours. A similar pattern is for summer and autumn, but the minimum ME values are shifted towards earlier hours when compared to winter ( 9 and 12 UTC), and the highest ME are for 6 UTC and afternoon hours. For spring, there is a change of sign for ME during the day. Night and early morning hours are overestimated, with maximum at 6 UTC. For daytime (9-18 UTC), the model underestimates the observed wind speed. For the wind direction, ME is negative for all seasons and hours. The exceptions are for spring 21
UTC and winter 15 UTC. The absolute values of ME for WDIR are very small for winter and are considerably higher for spring and, especially, summer months. For both spring and summer seasons, the largest errors are for 6, 18 and 21 UTC. For 21 UTC, $\mathrm{ME}$ is negative for summer and positive for spring.

The daily cycle of IOA for the air temperature is not so pronounced as for ME. Especially for winter, spring and autumn, the IOA is at a very high level throughout the day. For summer, IOA is lower for all hours, if compared to other seasons, and the lowest values are calculated for 3 and 6 UTC. For the relative humidity, the daily cycle is stronger, compared to air temperature, and is similar for all seasons. The maximum values are for $9-15$ UTC and there is a decrease in IOA for the night and morning. The IOA values are the highest for spring, when compared with other seasons.

There is practically no daily cycle in IOA for the wind speed. The IOA values differ between the seasons, but remain at ca. the same level for all hours. For wind direction, there is also no daily pattern in 
IOA values for winter and autumn. For spring and summer, there is a decrease in IOA for afternoon hours (for summer also for 21 UTC).

The spatial patterns of all simulated meteorological variables analysed are in agreement with the general climatological knowledge for this area (Fig. 6, T2 and WSPD presented as an example). For the winter air temperature, there is a strong decrease in air temperature towards the east, with increasing continentality of climate. The warming effect of the Baltic Sea is noticeable along the coast. The coldest areas are the mountains in the south and lowlands in the north-eastern part of Poland, influenced by a more continental climate. A very similar pattern is observed in the measurements. The model reproduced very well the warm belt along the sea coast and

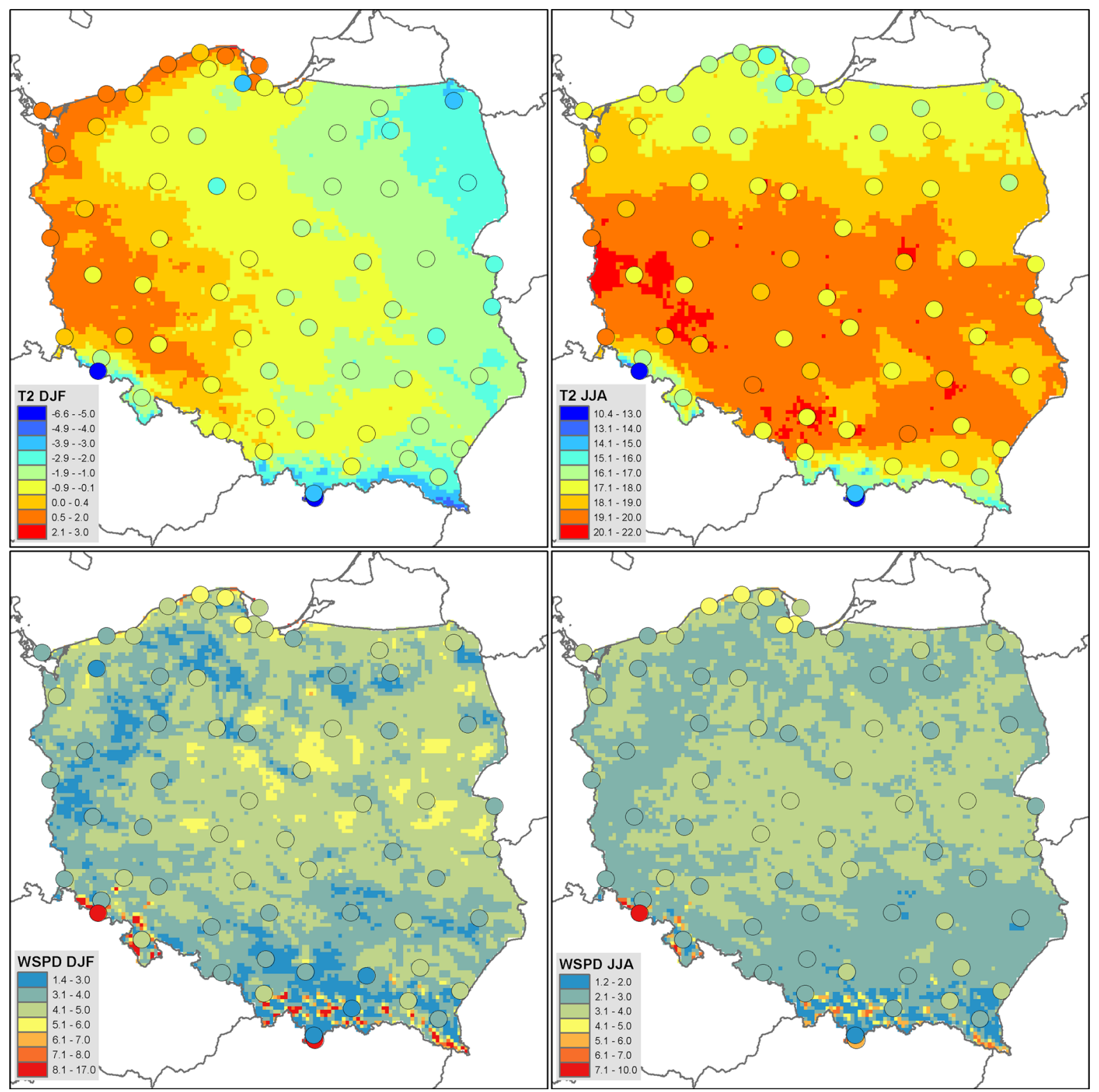

Figure 6

1981-2010 mean T2 $\left({ }^{\circ} \mathrm{C}\right.$ ) and WSPD ( $\mathrm{m} \mathrm{s}^{-1}$ ) for winter (DJF) and summer season calculated with WRF (gridded data) and measurements (points). Please notice inconsistent colour tables for winter and summer 
the cold region in NE Poland. However, the warm areas of SW Poland are slightly overestimated compared with the measurements. For summer, the S-N gradient is stronger compared to winter (except for the mountains in the south, where the air temperature is determined by terrain height) and related to the elevation of the sun. The modelled summer air temperature is also higher than that measured for almost all of the stations shown in Fig. 6. This overestimation is stable for the entire area and does not exceed $1 \mathrm{~K}$ for the majority of the meteorological stations used in this comparison. The wind speed does not show significant changes in spatial pattern if winter and summer seasons are compared. In general, a higher wind speed is calculated for the winter season, and this is in agreement with the general climatological knowledge for this region. The highest wind speeds are observed and calculated with the WRF model for the narrow belt along the seashore (individual grid cells with wind speed exceeding $6 \mathrm{~m} \mathrm{~s}^{-1}$ for both winter and summer seasons) and for the mountains in the south (above $8 \mathrm{~m} \mathrm{~s}^{-1}$ ), both for summer and winter seasons, and this is also confirmed by other studies for this area (e.g. CzERNECKI 2013). Large area of elevated wind speed in Central Poland is related to large frequency of winds from the west and lack of orographic barrier from this direction.

The spatial distribution of the IOA statistics for winter and summer seasons is presented in Fig. 7 with the example of T2 and WSPD. Both meteorological variables show some similar features. The IOA values are generally lower for the seashore stations and mountains in the south. This is both for winter and, especially, for summer, for which the IOA values are smaller. For the lowland stations of central Poland, the IOA values are very high for T2 for both seasons. For the wind speed, the lowland stations show smaller IOA in summer, compared to winter.

For the wind direction, the Pearson correlation coefficient for each station during the summer and winter seasons is presented in Fig. 8. There is a strong change in the model performance if winter and summer are compared. The correlation coefficient is higher for winter, when wind speed is, on average, stronger and exceeds 0.8 for the majority of the lowland stations. For summer, this statistic shows lower values for all the stations, and the decrease is the strongest for the seashore and the stations located in southern Poland. The station with the lowest $\mathrm{R}$ for wind direction, both for DJF and JJA, is Kłodzko, located in the mountain valley in SW Poland. This station is strongly influenced by the local orography (e.g. strong funnelling effects in winter during the frequent advections from the south); therefore, the spatial resolution of the WRF model $(5 \mathrm{~km} \times 5 \mathrm{~km}$ grid) may not be sufficient to properly resolve all the physical processes in this location.

In this study, the WRF model has been run for the 30-year period of 1981-2010. The question as to whether the model performance changes over time should be considered. This might be related to different reasons, including changes in the quality of the measurements, land use (constant land use was applied for all years) or the quality of the boundary and initial data. To address this question, the model performance has been summarized for each year and season separately and the model performance is summarized using the Taylor diagrams (Fig. 9). There is no statistically significant trend in model performance for all four meteorological parameters considered (only T2 and WSPD are presented for consistency) and all the model performance matrices used. The year-to-year changes in the model performance can be attributed to natural variability of climate. Year-to-year changes are especially large for the winter season and T2, with the two outliers in the plot for years 1982 and 2010. Year 2010 is also away from all the remaining points for winter WSPD (Fig. 9). For summer, all the years are clustered in the plot and characterized by similar values of correlation and standard deviation. For WSPD, some clustering is also present, especially in winter, and lower correlations for the summer season.

\section{Summary and Conclusions}

In our study, we have applied the regional domain Weather Research and Forecasting model to dynamically downscale the coarse-resolution Era-Interim data to a high spatial resolution of $5 \mathrm{~km} \times 5 \mathrm{~km}$ grid. The application of the regional meteorological model 


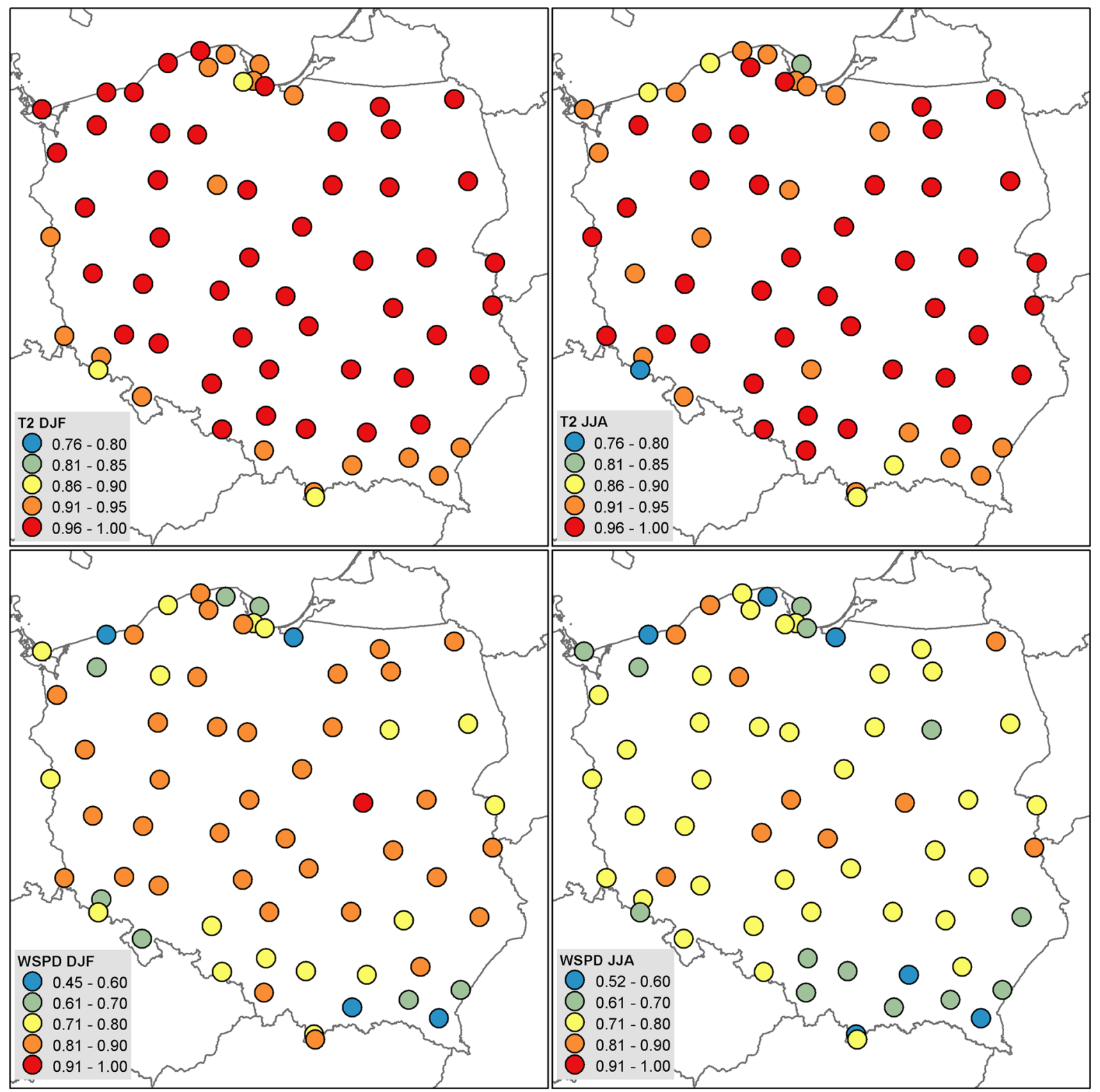

Figure 7

IOA for T2 and WSPD for the 1981-2010 period for the winter (DJF) and summer (JJA) seasons

WRF for the long-term period was undertaken to provide consistent spatial meteorological information for the entire area of Poland to various stakeholders who require this kind of information. Noticeably, this information has already supported ecological studies on tick activity (KIEWRA et al. 2014) and hydrological forecasting with HydroProg model (JEZIORSKA and
NIEDZIELSKI 2015, this issue). To our knowledge, this is the first study that analyses the WRF model performance for this geographical area at high spatial and temporal resolution and for a long-term period of 30 years. Therefore, the main focus of this paper was on the general quantification of the model performance for the meteorological variables, which are of 


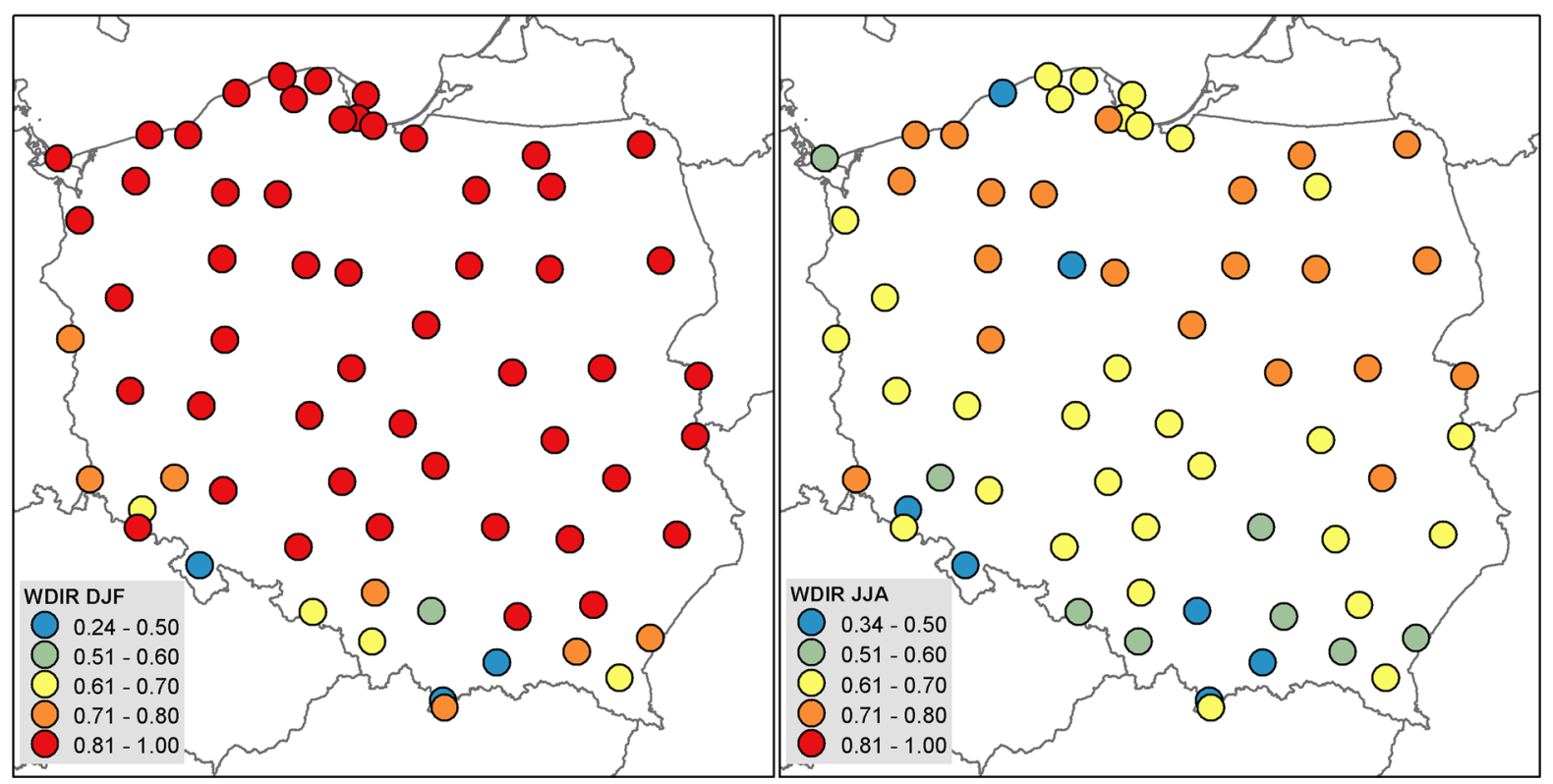

Figure 8

Correlation coefficient for WDIR for the 1981-2010 period for the winter (DJF) and summer (JJA) seasons

wide interest for other researches, e.g. for such problems as air temperature and humidity, wind speed and direction.

The WRF model results are, in general, in good agreement with the measurements. The model performance is better for the cold season and worse for warm months. This is especially clear for the mean error and might be linked with stronger convection in summer and larger variability of meteorological conditions. For summer, the WRF model was also found to be in worse agreement with the measurements for wind direction compared to other variables (T2 and RH2), and this supports the earlier findings by Czernecki (2013). For the wind direction, it is also noticeable that the current spatial resolution of the model domain may not be sufficient to properly resolve the wind conditions in areas of complex terrain. An example is the Kłodzko station, for which the model did not properly reflect strong funnelling effects, caused by specific terrain configuration. The other issues are related with wind measurements, including changes of sensors during this long-term period, e.g. in the 1990s.

There are strong seasonal and diurnal cycles in the model performance, which are especially clear for the mean error statistics. The WRF model underestimates the air temperatures for cold seasons and overestimates them for warm periods. Similar findings were presented for Eastern Europe (EURO-CORDEX subdomain EA) by KotLARSKI et al. (2014) using the multi-model ensemble approach. The underestimation in winter is observed for the entire day. Also for the warm season, the air temperature is overestimated for the entire day. The cycles are of opposite sign if $\mathrm{T} 2$ and RH2 are considered. All these cycles might be of importance for further application of the downscaling results, e.g. in hydrological modelling with the deterministic models. An example is TOPMODEL (JEZIORSKA and NIEDZIELSKI 2015, this issue), for which the temporal variability of evaporation has to be provided. There is a decrease in the model performance for wind speed and direction during hours with low wind speed. Large errors for these hours might also be related with errors in the wind speed measurements, which are of higher uncertainty for calm wind.

The index of agreement statistics is very high for air temperature, regardless of season. The IOA values are above 0.9 for all months and hours, which means that the WRF model results meet the acceptance 

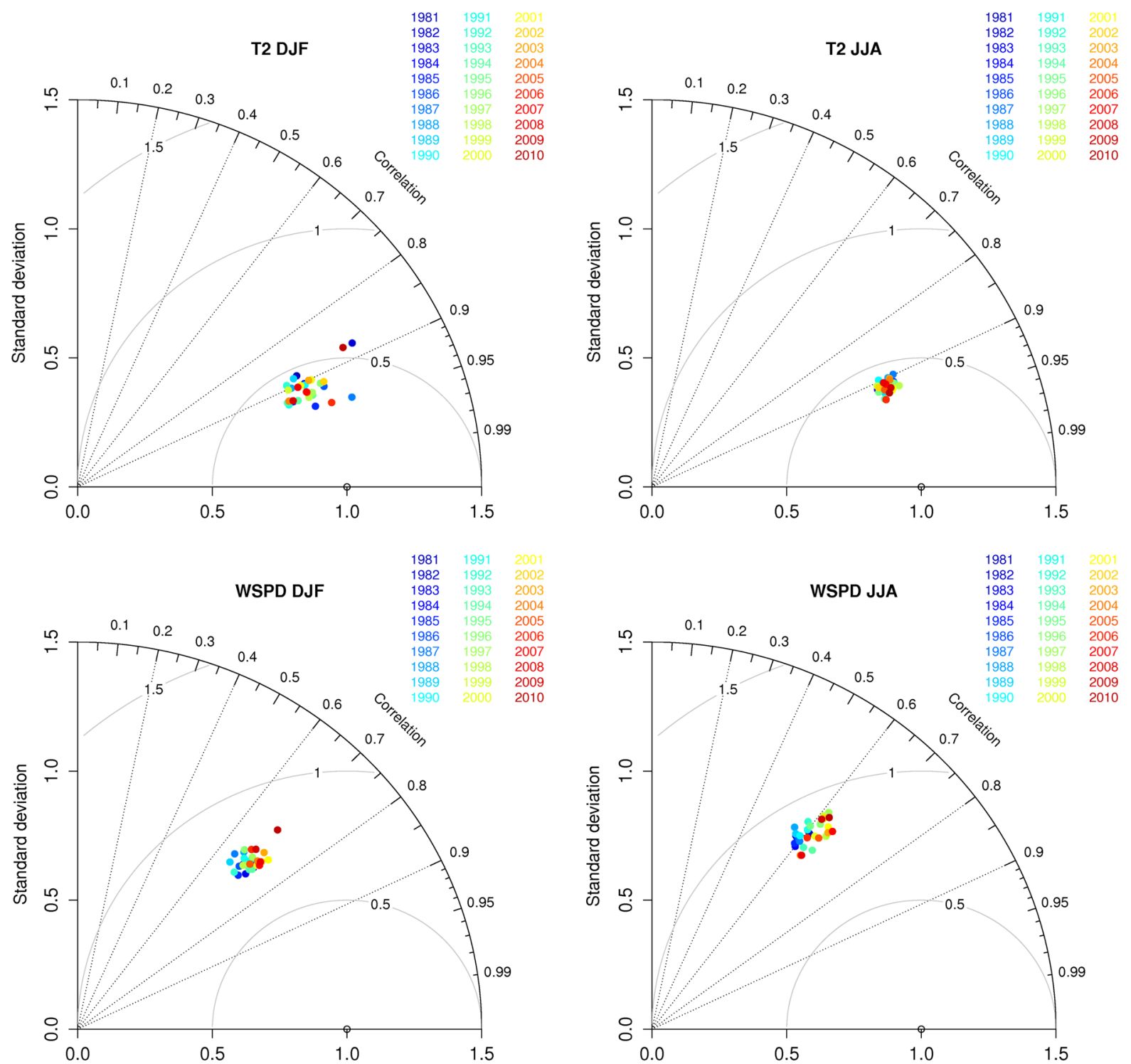

Figure 9

Normalized Taylor diagrams for T2 and WSPD for the winter (left column) and summer (right)

criteria proposed by EMERY et al. (2001) for air temperature at IOA $>0.7$. This means that the results obtained in this study are reliable and applicable for other research. The criteria are also met for wind speed (IOA >0.6). However, the mean error for air temperature usually exceeds the \pm 0.5 threshold proposed by EMERY et al. (2001), which suggests the need for application of the bias correction before the results are applied to other studies. For summer, there is a negative bias for air temperature and positive for relative humidity. The magnitude of this bias shows small spatial variability and is below $1 \mathrm{~K}$ for air temperature and $5 \%$ for relative humidity.

Spatial and seasonal changes in the index of agreement are small for air temperature and relative humidity. For the wind speed, the changes are more pronounced. For all the meteorological variables considered, the model performance is worse for the 
seashore and mountain areas. Especially for the mountains, this could be related to insufficient spatial resolution of the WRF model domain. This is especially clear if the specific stations, like Kłodzko, located in a valley, are considered. Here, strong wind funnelling effects are observed, which were not resolved properly by the model because of the smoothing of the terrain topography by the application of the $5 \mathrm{~km} \times 5 \mathrm{~km}$ grid. However, the uncertainty related to wind speed and direction measurements, mentioned above, is also of importance here.

Spatial distribution of meteorological variables obtained with the WRF model is in close agreement both with the station measurements and with general climatological knowledge for this area. Some seasonal and spatial features are well resolved by the model, including the warm belt along the sea coast, and the east-west gradient in spatial pattern of air temperature for winter. The $5 \mathrm{~km} \times 5 \mathrm{~km}$ model resolution results in a high spatial variability of the meteorological variables, especially for wind speed over mountainous regions. However, this resolution might still not be sufficient for solving local meteorological phenomena, which was demonstrated, e.g. by CzERneCKi (2013).

There is no statistically significant temporal trend in the model performance. The larger year-to-year changes in the model performance, e.g. for year 1982 and 2010 for the air temperature should, therefore, be linked with the natural variability of meteorological conditions.

The results of this study have generated a substantial spatial meteorological data set, which will be made available using the OGC services to a wide community. It is therefore important to know the limitations of this database before this information is used for other research. There is also a need for further evaluation of the WRF model results for the study area. This has already been undertaken by CZernecki (2013) for wind speed, WAłASZEK et al. (2014b) solar radiation and cloudiness and KRYZA et al. (2015) the planetary boundary layer height. This is especially important as the WRF model becomes widely used for this area for various applications, e.g. aerosol feedback effect studies (WERNER et al. 2015a, this issue), emission modelling (WERNER et al. 2015b) and wind energy (CZERNECKI 2013).

\section{Acknowledgments}

This work was supported by the National Science Centre (NCN), Poland (Grants No. N N404 014740 and UMO-2011/03/B/ST10/06226). Calculations were carried out in the Wroclaw Centre for Networking and Supercomputing (http://www.wcss. wroc.pl), Grant No. 170. Meteorological measurements for this work were provided by the Institute of Meteorology and Water Management, National Research Institute.

Open Access This article is distributed under the terms of the Creative Commons Attribution 4.0 International License (http:// creativecommons.org/licenses/by/4.0/), which permits unrestricted use, distribution, and reproduction in any medium, provided you give appropriate credit to the original author(s) and the source, provide a link to the Creative Commons license, and indicate if changes were made.

\section{REFERENCES}

Benestad, R.E., Hanssen-Bauer, I., Chen, D., Empirical-Statistical downscaling (World Scientific Publishing, Singapore 2008).

CZERnecKi, B. (2013), Creating wind field time-series over the Southern Baltic area using a dynamical downscaling approach, Meteorologische Zeitschrift 22, 587-593.

Dee, D.P., Uppala, S.M., Simmons, A.J., Berrisford, P., Poli, P., Kobayashi, S., Andrae, U., Balmaseda, M.A., Balsamo, G., Bauer, P., Bechtold, P., Beljatrs, A.C.M., Van D Berg, L., Bidlot, J., Bormann, N., Delsol, C., Dragani, R., Fuentes, M., Geer, A.J., Haimberger, L., Healy, S.B., Hersbach, H., Holm, E.V., Isaksen, L., Kallberg, P., Kohler, M., Matricardi, M., Mcnally, A.P., Monge-Sanz, B.M., Morcrette, J.J., Park, B.K., Peubey, C., De Rosnay, P., Tavolato, C., Thepaut, J.N. and VITART, F. (2011), The Era-Interim reanalysis: configuration and performance of the data assimilation system, Quarterly Journal of the Royal Meteorological Society 137, 553-597.

Emery, C., TaI, E., Greg, Y., 2001. Enhanced Meteorological Modeling and Performance Evaluation for Two Texas Ozone Episodes. Report to the Texas Natural Resource Conservation Commission, College Station, TX, USA, pp 235.

FuENTES U, HeIMANN D (2000): An improved statistical-dynamical downscaling scheme and its application to the Alpine precipitation climatology. Theor. Appl. Climatol. 65: 119-135.

Giorgi, F., and BATES, G.T. (1989), The climatological skill of a regional model over complex terrain, Monthly Weather Review 117, 2325-2347. 
Giorgi F., Gutowski W.G., 2015, Regional dynamical downscaling and the CORDEX initiative, Annual Review of Environment and Resources, doi: 10.1146/annurev-environ-102014-021217.

Grell, G.A., and Freitas, S.R. (2013), A scale and aerosol aware stochastic convective parameterization for weather and air quality modelling, Atmos Chem Phys Discuss 13, 23845-23893.

Hernandez-Ceballos, M.A., SkJoth, C.A., Garcia-Mozo, H., Bolivar, J.P. and Galan C. (2014), Improvement in the accuracy of back trajectories using WRF to identify pollen sources in southern Iberian Peninsula, International journal of biometeorology 58, 2031-2043.

Heikkila, U., Sandvik, A., Sorteberg, A. (2011), Dynamical downscaling of ERA-40 in complex terrain using the WRF regional climate model, Climate Dynamics 37, 1551-1564.

Hong, S-Y. and DudhiA, J. (2012), Next generation numerical weather prediction: bridging parameterization, explicit clouds and large eddies, Bull Amer Meteor Soc 93, http://dx.doi.org/10. 1175/2011BAMS3224.1.

Hong, S.Y. and Kanamitsu, M. (2014), Dynamical Downscaling: Fundamental Issues from a NWP Point of View and Recommendations, Asia-Pac. J. Atmos. Sci. 50(1), 83-104.

Hong, S.-Y., Noh, Y., and Dudhia, J. (2006), A New Vertical Diffusion Package with an Explicit Treatment of Entrainment Processes, Monthly Weather Review 134(9), 2318-2341.

Huth, R., Misovsky, J., Stepanek, P., Belda, M., Farda, A., Chladova, Z. and Pisoft, P. (2015), Comparative validation of statistical and dynamical downscaling models on a dense grid in central Europe: temperature, Theoretical and Applied Climatology doi: 10.1007/s00704-014-1190-3.

Iacono, M. J., Delamere, J. S., Mlawer, E. J., Shephard, M. W., Clough, S. A., and Collins, W. D. (2008), Radiative forcing by long-lived greenhouse gases: Calculations with the AER radiative transfer models, Journal of Geophysical Research: Atmospheres 113(D13), D13103. doi:10.1029/2008JD009944.

JeZiorska, J. and Niedzielski, T. (2015), Applicability of TOPMODEL in the mountainous catchments in the upper Nysa Kłodzka River basin (SW Poland), Pure and Applied Geophysics (in revision, this issue).

Katragkou E., Garcia-Diez M., Vautard R., Sobolowski S., Zanis P., Alexandri G., Cardoso R.M., Colette A., Fernandex J., Gobiet A., Goergen K., Karacostas T., Knist S., Mayer S., Soares P.M.M., Pytharoulis I., Tegoulias I., Tsikerdekis A., $\mathrm{J}_{\mathrm{ACOB}}$ D., 2015, Regional climate hindcast simulations with EURO-CORDEX: evaluation of a WRF multi-physics ensemble, Geosci. Model Dev. doi:10.5194/gmd-8-603-2015.

KaIN, J. S. (2004), The Kain-Fritsch Convective Parameterization: An Update, Journal of Applied Meteorology 43(1), 170-181.

Kendall, M.G., (1970), Rank Correlation Methods. 4th Ed. (Griffin 1976).

Kiewra, D., Kryza, M. and Szymanowski, M. (2014), Influence of selected meteorological variables on the questing activity of Ixodes ricinus ticks in Lower Silesia, SW Poland, Journal of Vector Ecology 39, 138-145.

Kim, J.-W., Chang, J.-T., BaKer, N.L., Wilks, D.S. and Gates, W.L. (1984), The statistical problem of climate inversion: determination of the relationship between local and large-scale climate, Monthly Weather Review 112, 2069-2077.

Kryza, M., Werner, M., Wałaszek, K. and Dore, A.J. (2013), Application and evaluation of the WRF model for high-resolution forecasting of rainfall-a case study of SW Poland, Meteorologische Zeitschrift 22, 595-601.
Kryza, M., Guzikowski, J., Werner, M., Szymanowski, M., WałaszeK, K. and Dore A.J. (2015), Performance of the WRF model and sensitivity to microphysics, planetary boundary layer and radiation schemes: a case study from Poland, Atmospheric Research (in revision).

Kotlarski S., Keuler K., Christensen O.B., Colette A., Deque M., Gobiet A., Goergen K., Jacob D., Luthi D., van MeigaArd E., Nikulin G., Schar C., Teichmann C., Vautard R., WarrachSAGi K., Wulfmeyer V., 2014, Regional climate modelling on European scales: a joint standard evaluation of the EUROCORDEX RCM ensamble, Geosci. Model Dev. doi:10.5194/ gmd-7-1297-2014.

Lorenc, H., Atlas Klimatu Polski, (IMGW 2005) (in Polish).

ManN, H.B. (1945), Nonparametric tests against trend, Econometrica 13, 245-259.

Marosz, M. and JAKUSIK, E. (2014), Downscaling of PDFs of daily air temperature on northern Poland: assessment of predictors, Meteorologische Zeitschrift 23, 167-174.

Marosz, M., Wóscik, R., Pilarski, M. and Miętus, M. (2013), Extreme daily precipitation totals in Poland during summer: the role of regional atmospheric circulation, Clim Res 56, 245-259.

Mlawer, E. J., Taubman, S. J., Brown, P. D., Iacono, M. J., and Clough, S.A. (1997), Radiative transfer for inhomogeneous atmospheres: RRTM, a validated correlated- $k$ model for the longwave, Journal of Geophysical Research: Atmospheres 102(D14), 16663-16682.

Murphy, J. (1999), An evaluation of statistical and dynamical techniques for downscaling local climate, J. Climate 12, 2256-2284.

OJRZyńsKa, H., KryZa, M., Wałaszek, K., SZymanowski, M., Werner, M. and Dore A.J. (2015), High resolution dynamical downscaling of ERA-Interim using the WRF regional climate model for the area of Poland. Part 2: model performance with respect to automatically derived circulation types, Pure and Applied Geophysics. doi:10.1007/s00024-016-1273-4.

Pavlik, D., Soehl, D., Pluntke, T., Mykhnovych, A. and BernHOFER, C. (2011), Dynamical downscaling of global climate projections for Eastern Europe with a horizontal resolution of 7 km, Environ Earth Scie 65, 1475-1482.

Pielke, R.A. Sr (2013), Comments on "The North American Regional Climate Change Assessment Program: Overview of Phase I results", Bull Amer Meteor Soc 1075-1077.

Reyers M, Pinto JG, Moemken J (2015): Statistical-dynamical downscaling for wind energy potentials: evaluation and applications to decadal hindcasts and climate change projections. Int. J. Climatol. 35: 229-244.

Skamarock, W.C., Klemp, J.B., Dudhia, J., Gill, D.O., Barker, D.M., Duda, M., Huang, X.-Y., Wang, W. and Powers J.G., A description of the advanced research WRF version 3, (Technical report TN-475 + STR, NCAR 2008).

Shrestha, D.L, Robertson, D.E., Wang, Q.J., Pagano, T.C. and HaPUARACHCHI H.A.P. (2013), Evaluation of numerical weather prediction model precipitation forecasts for short-term streamflow forecasting purpose, Hydrol Earth Syst Sci 17, 1913-1931.

Soares, P.M.M., Cardoso, R.M., Miranda, P.M.A., DE Medeiros, J., Belo-Pereira, M., EsPirito-Santo, F. (2012), WRF high resolution dynamical downscaling of ERA-Interim for Portugal, Climate Dynamics 39, 2497-2522.

Tad, W.-K., Simpson, J., and McCumber, M. (1989), An Ice-Water Saturation Adjustment, Monthly Weather Review 117(1), 231-235. 
TAYLOR, K.E. (2001), Summarizing multiple aspects of model performance in a single diagram, Journal of Geophysical Research 106, 7183-7192.

WataszeK, K., Kryza, M. and Werner, M. (2014), Evaluation of the WRF meteorological model results during a high ozone episode in SW Poland-the role of model initial conditions, International Journal of Environment and Pollution 54, 193-202.

Wałaszek, K., Kryza, M. and Werner M. (2014), A Sensitivity Analysis of the WRF Model to Shortwave Radiation Schemes for Air Quality Purposes and Evaluation with Observational Data, Air Pollution Modeling and its Application XXIII, pp. 539-543.

Wałaszek, K., Kryza, M., Szymanowski, M., Werner, M. and OJRZYŃSKa H. (2015), Sensitivity study of cloud cover and ozone modeling to microphysics parameterization, Pure and Applied Geophysics (this issue).

Werner, M., Kryza, M., Dore, A.J., Błaś, M., Hallsworth, S., VIEno, M., TANG, Y.S. and Smith R.I. (2011), Modelling of marine base cation emissions, concentrations and deposition in the UK, Atmospheric Chemistry and Physics 11, 1023-1037.

Werner, M., Kryza, M., SkJøth A.C., WałaszeK, K., Dore A.J. and OJRZYŃSKA, H. (2015a), Aerosol-radiation feedback and PM10 air concentrations over Poland, Pure and Applied Geophysics (this issue).

Werner, M., Skjøth A.C., Kryza, M. And Dore, A.J. (2015b), Understanding emissions of ammonia from buildings and application of fertilizers: an example from Poland, Biogeosciences Discuss.

(Received January 20, 2015, revised February 16, 2016, accepted March 11, 2016, Published online March 30, 2016) 